\title{
Tipping off pruning and use of biofertilizer in the growth of Pecan trees
}

\author{
Hélio Lange Junior ${ }^{1}$, Carlos Roberto Martins², Elisane Schwartz ${ }^{3}$, Marcelo Barbosa Malgarim ${ }^{4}$
}

\begin{abstract}
In Brazil, the cultivation of pecan trees has substantially increased in the last years, thus requiring the development of scientific research and technologies to improve it. Thus, the aim of this study was to evaluate the tipping off effect associated with the use of biofertilizer in the growth of newly implanted plants in their final site. The treatments consisted of : control; application of "supermagro" biofertilizer; tipping off of plants, and tipping off associated with the use of biofertilizer. The variables evaluated were: plant height; plant growth rate; stem thickness; number of leaves, and number of leaves/stem height ratio. In addition, leaf nutrient content analysis was performed. Tipping off and the use of biofertilizer provide greater growth of the plant height and cultivar scion diameter after sprouting. Thus, tipping off associated with biofertilizer can be used in the early phase of the pecan orchard implantation to provide the best plant development.
\end{abstract}

Index terms: Pecan culture; Barton cultivar; Carya illinoinensis; Management; Fruit culture.

\section{Poda de desponte e uso de biofertilizante no crescimento de Nogueiras-pecã}

Resumo- O objetivo deste estudo foi avaliar o efeito de desponte associado ao uso de biofertilizantes no crescimento da planta, da cultivar Barton, recém-implantada no local definitivo. O experimento foi conduzido em uma propriedade rural, no município de Morro Redondo (RS). Os tratamentos consistiram em: testemunha; aplicação do biofertilizante supermagro; desponte de plantas, e desponte associado à aplicação do biofertilizante. O estudo foi conduzido entre julho de 2017 e setembro de 2018. A prática de desponte na poda de formação da nogueira-pecã promoveu o crescimento da planta com relação à altura, ao diâmetro do enxerto, à estimulação no tempo de brotação e ao número de folhas. A utilização do biofertilizante estimulou maior crescimento da altura das plantas. Além disso,

Corresponding author: heliojr_agro@hotmail.com.

Received: May 04, 2020 Accepted: June 26, 2020

Copyright: All the contents of this journal, except where otherwise noted, is licensed under a Creative Commons Attribution License.

(cc) EY foi observada maior concentração de nutrientes por via foliar nas plantas que receberam o desponte associado ao biofertilizante. A prática de desponte e o uso do biofertilizante apresentaram maior crescimento da altura da planta e diâmetro da cultivar-copa no período avaliado. Assim, a utilização de desponte, associado ao uso de biofertilizante, é uma alternativa que pode ser utilizada na fase inicial de implantação do pomar de nogueiras-pecã para proporcionar o melhor desenvolvimento da planta. Termos para indexação: Pecanicultura; Cultivar Barton; Carya illinoinensis; Manejo; Fruticultura.

\footnotetext{
${ }^{1}$ Agronomist, Master in Agronomy, Universidade Federal de Pelotas, Capão do Leão-RS Brazil. E-mail: heliojr_agro@hotmail.com. (ORcID 0000-0003-0887-4186)

${ }^{2}$ Agronomist, Doctor of Agronomy, Researcher at Embrapa Temperate Climate, Pelotas-RS, Brazil. E-mail: carlos.r.martins@embrapa.br. (ORCID 0000-0001-8833-1629)

${ }^{3}$ Agronomist, Doctor of Agronomy, Professor at the Instituto Federal Sul-rio-grandense, Campus Visconde da Graça, Pelotas- RS, Brazil. E-mail: elisane.schwartz@gmail.com (ORCID 0000-0001-9810-4833)

${ }^{4}$ Agronomist, Doctor of Agronomy, Professor at the Fruit Department. Graduate Program in Agronomy, Universidade Federal de Pelotas, Capão do Leão-RS, Brazil. E-mail: malgarim@yahoo.com (ORCID 0000-0002-3584-5228)
} 
In Brazil, the cultivation of pecan trees comprises the South and Southeast regions, but its production is mainly concentrated in the states of Rio Grande do Sul, Santa Catarina, and Paraná. The largest cultivated area and fruit production are located in Rio Grande do Sul, which currently owns more than 5,000 hectares of planted area (BILHARVA et al., 2018).

The implantation phase of the pecan orchard has a slow initial development and uneven, misplaced, forked, and unnecessary sprouts, which hinders the initial adaptation phase. In addition to hindering management, this slow initial development predisposes to phytosanitary problems and their consequences (POLLETO et al., 2015).

A study performed in Australia by Wood and Stahmann (2004) showed that pruning is a viable option for the traditional strategies of pecan orchard management as it provides means through which greater control over the tree and orchard can be achieved. Moreover, the use of leaf biofertilizers can be an important alternative for the supply of essential nutrients and stimulation of plant development since they are rich in nutrients and have important bioactive compounds, which may stimulate higher growth (SILVA et al., 2007; LOPEZ et al, 2016). A study by Araújo et al. (2007) showed that the use of "supermagro" biofertilizer was efficient for the supply of nutrients in Arabica coffee trees (Coffea arabica L.). Another study, performed with Annona squamosa L., discovered that the fruit productivity increases with the use of leaf biofertilizers (LEONEL et al, 2015).

Even though pecan trees have been introduced in the country over a century ago, few studies on the initial development of plants in the orchard implantation phase have been performed to evaluate plant growth and performance (POLETTO et al., 2015; BOSCARDIN et al., 2017; BILHARVA et al., 2018). Thus, the aim of this study was to evaluate the tipping off effect associated with the use of biofertilizer in the initial growth of pecan trees of the Barton cultivar.

The experiment was performed in a rural property located in the Açoita Cavalo colony in the municipality of Morro Redondo-RS. The orchard was implanted in July 2017 with the Barton cultivar. The geographical coordinates are: latitude $31^{\circ} 41^{\prime} 42^{\prime \prime} \mathrm{S}$, longitude $52^{\circ} 36^{\prime} 40^{\prime \prime}$ $\mathrm{W}$ and altitude of $245 \mathrm{~m}$. The soil was identified as Acrisol, which has as textural characteristic such as B horizon. The climate of the region is subtropical humid - $\mathrm{Cfa}$, according to Köppen, and it presents well-distributed rainfalls throughout the year (EMBRAPA, 2017).

Tipping off was performed on August 26, 2017, in previously demarcated plants. Approximately five centimeters of the plant apex were removed, according to the methodology of Fronza and Hamann (2016), with the aid of manual pruning shears.

The biofertilizer used was the "supermagro"; which is the product of anaerobic fermentation of a mixture of products, according to the methodology of Leite and Meira (2012). "Supermagro" applications were performed with a Tramontina ${ }^{\circledR} 1$ L manual sprayer. The first "supermagro" application was performed on December 13, 2017, then, six other applications were performed within a 14-day interval.

The variables evaluated were: plant height; plant growth rate; stem thickness; number of leaves; number of leaves/plant height ratio; sprouting time; rootstock diameter, and graft diameter. Based on the data obtained from the evaluations and the methodology of Benincasa (2003), the absolute growth rates for each variable were estimated.

Plant height was obtained through a Momfort ${ }^{\mathbb{B}}$ 2-meter wood scale and measured in centimeters from the graft callus to the plant apex. The measurements were taken on September 2, 2017, December 13, 2017, and August 8, 2018. The absolute growth rate of the plant height (AGRPH) was calculated through equation (A) and expressed in $\mathrm{cm} \cdot \mathrm{d}^{-1}: \mathrm{H} 2-\mathrm{H} 1(\mathrm{t} 2-\mathrm{t} 1)$. Where: H1- Measurement of plant height at time t1, in $\mathrm{cm}$; H2Measurement of plant height at time t2, in cm; (t2 - t t)Time interval between collections, in days.

Measurement of the rootstock diameter was performed with an Matrix Tools for Existence ${ }^{\circledR}$ digital caliper. The reading site was established through the graft callus, from which $55 \mathrm{~mm}$ were measured down, and then the rootstock diameter was read.

The absolute growth rate of the rootstock (AGRRST) and graft (AGRGST) stem thickness was calculated through equation (B) and expressed in $\mathrm{mm} \cdot \mathrm{d}^{-1}$ : D2-D1(t2-t1). Where: D1- Measurement of rootstock/graft diameter at time t1, in mm; D2- Measurement of rootstock/ graft diameter at time t2, in $\mathbf{m m}$; ( $\mathbf{t} \mathbf{2}-\mathbf{t} \mathbf{1})$ - Time interval between collections, in days.

A randomized complete block design with four replications was used. Each plot consisted of eight plants distributed in $11 \times 11 \mathrm{~m}$ spacing between rows and between plants within rows, respectively. The treatments (T) consisted of: T1 - a group of control plants; T2 application of biofertilizer; T3 - tipping off, and T4 - tipping off and application of biofertilizer. The study was conducted between July 2017 and September 2018.

Statistical analysis and graphical development were performed with the aid of $\mathrm{SPSS}^{\circ}$ version 25.0 and GraphPad Prism 8.0 for Windows. The ShapiroWilk normality test and Levene's test for homogeneity of variances were performed. Then, the results were submitted to the analysis of variance, which considered the measurement of each evaluation and the time between evaluations to obtain the mean of the measurement estimated in time (MMET). The relationship between plant height and number of leaves was investigated using Pearson correlation coefficients. To compare the means, the Tukey and Dunnett's test at 5\% probability was used. 
The application of biofertilizer, tipping off pruning and association of tipping off pruning with biofertilizer provided higher plant growth, which was evidenced by the plant height and cultivar scion diameter (Table 1).

Linear growth behavior of the plant height was observed, and plants that received treatment with tipping off, biofertilizer and tipping off associated with biofertilizer had a higher growth effect after sprouting. It is noteworthy that the plants that received the nine applications of biofertilizer presented greater stimuli in plant height growth when compared to the control ones, with an MMET of $66.62 \mathrm{~cm}(\mathrm{p}=0.034)$ (Table 1). According to Araújo (2007), the use of biofertilizer has promoted the action of physiological activities and stimulated the plant development, acting on the growth of its shoot parts, flowering, and even rooting. A study performed by Celedonio et al. (2013) showed that the use of biofertilizer after pruning provided better growth of fig trees.

Concerning the absolute growth rates both the plant height and the rootstock and graft diameters, it was observed that the treatments that underwent tipping off and/or received biofertilizer presented higher values (Table 1). According to Fronza and Hamann (2016), tipping off of plants can stimulate higher stem growth in both graft and rootstock. In addition, the authors point out that this practice must occur in plants since the apical buds are juxtaposed, which can lead to the formation of pitchforks, "chicken feet", and low vigor in new sprouts.
Stimulation in the reduction of the plant sprouting time was observed in the groups that received the tipping off pruning and biofertilizer, with a reduction of up to 19 days in the mean time of the pecan tree sprouting. On the one hand, tipping off pruning had a greater effect on the reduction of the plant sprouting time, taking a mean time of 14.38 days; on the other, plants receiving tipping off pruning associated with biofertilizer took a mean time of 20.68 days (Table 1 ). Thus, tipping off pruning stimulated the plant sprouting. This early sprouting is favorable as long as no late frost occurs, which may damage the leaf area. In the year of this experiment, there was no late frost formation.

A similar effect was observed when the mean number of leaves was evaluated. The treatments with the application of biofertilizer and tipping off had significant difference regarding to the control one. It was found that plants that received only the treatment of tipping off obtained the highest absolute value, with a mean amount of 339.37 leaves, and significantly differed from the control, which presented 78 leaves less $(\mathrm{p}=0.04$; Table 1$)$.

Table 1. Means for sprouting time and number of leaves, height, graft diameter, and rootstock diameter of pecan trees submitted to the treatments of tipping off, biofertilizer, and tipping off + biofertilizer. Morro Redondo (State of Rio Grande do Sul, Brazil), Harvest 2017/2018.

\begin{tabular}{lcccc}
\hline & Control & Biofertilizer & Tipping off & Biofertilizer and tipping off \\
$\begin{array}{l}\text { Sprouting time } \\
\text { (in days) }\end{array}$ & $33.13^{\mathrm{A}}$ & $33.13^{\mathrm{A}}$ & $14.38^{\mathrm{B}^{*}}$ & $20.68^{\mathrm{B}}$ \\
Number of leaves & $261.00^{\mathrm{B}}$ & $323.37^{\mathrm{A}}$ & $339.37^{\mathrm{A}^{*}}$ & $308.12^{\mathrm{A}}$ \\
Plant Height $(\mathbf{c m})$ & & & \\
${ }^{1}$ MMET & $59.75^{\mathrm{B}}$ & $66.62^{\mathrm{A}^{*}}$ & $65.87^{\mathrm{A}}$ & $66.54^{\mathrm{A}}$ \\
${ }^{2}$ AGR & 0.0683 & 0.1085 & 0.1162 & 0.1132 \\
Graft diameter $(\mathbf{m m})$ & & & & \\
${ }^{1}$ MMET & $7.53^{\mathrm{B}}$ & $8.28^{\mathrm{AB}}$ & $8.74^{\mathrm{A}}$ & $7.87^{\mathrm{AB}}$ \\
${ }^{2} \mathrm{AGR}$ & 0.0108 & 0.0151 & 0.0175 & 0.0151 \\
Rootstock diameter $(\mathbf{m m})$ & & & & \\
${ }^{1}$ MMET & $9.84^{\mathrm{A}}$ & $10.74^{\mathrm{A}}$ & $10.73^{\mathrm{A}}$ & $9.89^{\mathrm{A}}$ \\
${ }^{2}$ AGR & 0.0091 & 0.0129 & 0.0162 & 0.0120 \\
\hline
\end{tabular}

Means followed by equal uppercase letters in the same line do not statistically differ by Tukey's test. *Statistically significant difference compared to the control group by Dunnett's test $(\mathrm{p}<0.05) .{ }^{1}$ Mean of the Measurement Estimated in Time. ${ }^{2}$ Absolute Growth Rate. 
It was observed that, in the correlation analysis (Table 2), there was a significant influence of height on the number of leaves of the plants that received the treatments of tipping off $(\mathrm{r}=0.716)$, biofertilizer $(\mathrm{r}=0.742)$, and tipping off associated with biofertilizer $(\mathrm{r}=0.891)$.
Furthermore, plants from the treatment of tipping off and biofertilizer showed a significant positive correlation between the number of leaves and graft $(r=0.771)$ and rootstock $(r=0.742)$ diameters.

Table 2. Relation between the mean number of leaves, plant height (PH), graft diameter (GRAD), and rootstock diameter (ROOTD) of pecan trees submitted to the treatments of: tipping off, biofertilizer, and tipping off + biofertilizer. Morro Redondo (State of Rio Grande do Sul, Brazil), Harvest 2017/2018.

\begin{tabular}{|c|c|c|c|c|c|c|c|}
\hline & Number of leaves & $\mathrm{PH}$ & $\begin{array}{c}{ }^{*} \mathrm{r} \\
\text { P-value }\end{array}$ & GRAD & $\begin{array}{c}{ }^{*} \mathrm{r} \\
\text { P-value }\end{array}$ & ROOTD & $\begin{array}{c}{ }^{*} \mathrm{r} \\
\text { P-value } \\
\end{array}$ \\
\hline Control & $261.00 \pm 40.91$ & $23.25 \pm 12.66$ & $\begin{array}{c}0.420 \\
p=0.301\end{array}$ & $3.66 \pm 1.67$ & $\begin{array}{c}0.396 \\
p=0.331\end{array}$ & $3.10 \pm 1.09$ & $\begin{array}{c}0.562 \\
p=0.147\end{array}$ \\
\hline Biofertilizer & $323.37 \pm 83.23$ & $36.68 \pm 18.97$ & $\begin{array}{c}0.742 \\
p=0.035\end{array}$ & $5.13 \pm 1.81$ & $\begin{array}{c}0.433 \\
p=0.284\end{array}$ & $4.39 \pm 1.93$ & $\begin{array}{c}0.374 \\
\mathrm{p}=0.361\end{array}$ \\
\hline Tipping off & $339.37 \pm 69.45$ & $39.50 \pm 13.59$ & $\begin{array}{c}0.716 \\
p=0.046\end{array}$ & $5.94 \pm 1.40$ & $\begin{array}{c}0.502 \\
p=0.205\end{array}$ & $5.50 \pm 2.02$ & $\begin{array}{c}0.537 \\
p=0.170\end{array}$ \\
\hline $\begin{array}{l}\text { Tipping off and } \\
\text { biofertilizer }\end{array}$ & $308.12 \pm 51.55$ & $38.50 \pm 14.60$ & $\begin{array}{c}0.891 \\
\mathrm{p}=0.003\end{array}$ & $5.14 \pm 2.09$ & $\begin{array}{c}0.771 \\
p=0.025\end{array}$ & $4.08 \pm 2.03$ & $\begin{array}{c}0.742 \\
p=0.035\end{array}$ \\
\hline
\end{tabular}

* Pearson correlation coefficient.

Although the main apparent organ of nutrient absorption is the root, plants that received the treatment of tipping off and biofertilizer may have had greater leaf nutrient absorption due to the stimulus that the tipping off pruning exerted on the leaf production. This situation may have enabled greater assimilation of nutrients, which were shifted to plant growth. Moreover, as the biofertilizer was applied, there was a greater essential nutrient supply via leaf, which may have boosted the growth of plant height and cultivar scion diameter. This result corroborates a study performed with yellow passion fruit trees (Passiflora edulis Sims $f$. flavicarpa Deg.) in the region of Remígio (State of Pernambuco, Brazil), in which the authors reported that the use of "supermagro" biofertilizer stimulated the stem diameter growth, but it did not interfere in the culture productive capacity (JUNIOR et al., 2006).
Regarding the macro-and-micronutrient contents in the leaf tissues, it was possible to verify higher levels of copper, zinc, manganese, iron, and boron in the pecan leaves that received the tipping off and biofertilizer, demonstrating that the biofertilizer may have contributed to higher nutrient concentrations in the leaf tissue. The plants that suffered tipping off had lower concentrations of calcium, sulfur, and iron nutrients in the leaf tissue (Table 3). This result may be related to nutrient mobility. Immovable elements, such as calcium, sulfur, iron, and boron, do not have the ability to translocate nutrient stocks existent in the plant (TAIZ et al., 2009). Thus, after tipping off, nutritional elements allocated in the apical bud may have been removed in the pruning, which may justify the lower contents of these nutrients in pecan leaves. Wells et al. (2012) mention that zinc is an important nutritional element in pecan trees, as in its deficiency, chlorotic leaves with wavy margins may appear. In addition to the nutritional aspects, by using biofertilizers, we seek a phytotherapeutic action that promotes an inhibitory and protective action against pathogens and pest repellent through nutritional balance (ARAÚJO et al., 2007), as well as provides a cost reduction for the producer to purchase external inputs (ANTONIOLLI et al., 2009). 
Table 3. Chemical analysis of the leaf nutrient contents according to the treatment groups in pecan trees. Morro Redondo (State of Rio Grande do Sul, Brazil), Harvest 2017/2018.

\begin{tabular}{cccccc}
\hline & Control & Biofertilizer & $\begin{array}{c}\text { Tipping } \\
\text { off }\end{array}$ & $\begin{array}{c}\text { Biofertilizer and } \\
\text { Tipping off }\end{array}$ & $\begin{array}{c}\text { Adequate Values } \\
\text { Range }\end{array}$ \\
\hline Nitrogen $(\mathrm{TKN})-\%(\mathrm{~m} / \mathrm{m})$ & 1.6 & 2.7 & 2.8 & 2.6 & $2.5-3.0$ \\
Total phosphorus $-\%(\mathrm{~m} / \mathrm{m})$ & 0.21 & 0.18 & 0.16 & 0.20 & $0.14-0.30$ \\
Total potassium $-\%(\mathrm{~m} / \mathrm{m})$ & 0.83 & 0.83 & 0.67 & 0.78 & $1.3-2.5$ \\
Total calcium $-\%(\mathrm{~m} / \mathrm{m})$ & 1.1 & 1.0 & 0.79 & 1.1 & $1.3-1.7$ \\
Total magnesium $-\%(\mathrm{~m} / \mathrm{m})$ & 0.34 & 0.33 & 0.26 & 0.33 & $0.3-0.6$ \\
Total sulfur $-\%(\mathrm{~m} / \mathrm{m})$ & 0.28 & 0.24 & 0.21 & 0.27 & - \\
Total copper $-(\mathrm{mg} / \mathrm{kg})$ & 3.0 & 3.0 & 3.0 & 5.0 & $6-30$ \\
Total zinc $-(\mathrm{mg} / \mathrm{kg})$ & 191.0 & 175.0 & 165.0 & 279.0 & $50-100$ \\
Total iron $-(\mathrm{mg} / \mathrm{kg})$ & 60.0 & 56.0 & 47.0 & 76.0 & $80-300$ \\
Total manganese $-(\mathrm{mg} / \mathrm{kg})$ & 760.0 & 852.0 & 638.0 & 742.0 & $100-800$ \\
Total boron $-(\mathrm{mg} / \mathrm{kg})$ & 30.0 & 34.0 & 28.0 & 36.0 & $50-100$ \\
\hline
\end{tabular}

${ }^{\mathrm{a} C Q F S-R S / S C ~(2016) . ~}$

In conclusion, our results showed tipping off and the use of biofertilizer provide greater growth of the plant height and cultivar scion diameter after sprouting. Furthermore, they demonstrate a significant positive relationship between the number of leaves and plant growth. Therefore, tipping off associated with biofertilizer can be used in the early phase of the pecan orchard implantation to provide the best plant development.

\section{References}

ANTONIOLLI, Z.I.; STEFFEN, G.P.K.; STEFFEN,R.B. Utilização de casca de arroz e esterco bovino como substrato para a multiplicação de eisenia fetida savigny (1826). Ciência e Agrotecnologia, Lavras, v.33, n.3, p.824-830, 2009.

A R A ÚJO, J.B.S.; CARVALHO, G.J.D.; GUIMARÃES,R.J.; CARVALHO, J.G.D. Composto orgânico e biofertilizante na nutrição do cafeeiro em formação no sistema orgânico: teores foliares. Coffee Science, Lavras, v.2, n.1, p.20-28, 2007. Disponível em: http://www.sbicafe.ufv.br:80/handle/123456789/5626. Acesso em: 04 maio.2020.

BENINCASA, M.M.P. Análise de crescimento de plantas. Jaboticabal: Funep, 2003. 41p.
BILHARVA, M.G.; MARTINS, C.R.; HAMANN, J.J.; FRONZA, D.; DE MARCO, R.; MALGARIM, M.B.Pecan: from research to the brazilian reality. Journal of Experimental Agriculture International, Gurgaon, v.23, n.6, p.1-16, 2018.

BOSCARDIN, J.; COSTA, E. C. A nogueira-pecã no Brasil: Uma revisão entomológica. Ciência Florestal, v.28, n.1, p. 456-468, 2018.

CELEDONIO, C.A.; DE MEDEIROS, J.F.; DA SILVA, F.L.; SARAIVA, K.R.; ALBUQUERQUE, A.H.P.Crescimento da figueira em três ambientes de cultivo, sob aplicação de biofertilizante bovino via fertirrigação. Revista Brasileira de Agricultura Irrigada - RBAI, Fortaleza, v.7, n.6, p.358-370, 2013. Disponível em: http:// inovagri.org.br/revista/index.php/rbai/article/ view/195/pdf_153. Acesso em: 04 maio. 2020.

CQFS-RS/SC - Comissão de Química e Fertilidade do Solo. Manual de calagem e adubação para os Estados do Rio Grande do Sul e de Santa Catarina.11.ed. Frederico Westphalen: Sociedade Brasileira de Ciência do Solo, 2016. 217p.

Embrapa de Clima Temperado. Atlas climático da Região Sul do Brasil: estados do Paraná, Santa Catarina e Rio Grande do Sul. (Embrapa Clima Temperado, Documentos, 443), 2017.145f. 
FRONZA, D.; HAMANN, J.J. Técnicas para o cultivo de Nogueira-pecã. Santa Maria: Colégio Politécnico da USFM. Núcleo de Fruticultura Irrigada, 2016. p.424.

JUNIOR, F.R.; CAVALCANTE, L.F.; BURITI, E.D.S.Crescimento e produção do maracujazeiro-amarelo em solo com biofertilizantes e adubação mineral com npk. Revista Caatinga, Mossoró, v.5, p.134-145, 2006. Disponível em: https://periodicos.ufersa.edu.br/index. php/caatinga/article/view/339. Acesso em: 04 maio.2020.

LEITE, C.D.; MEIRA, A.L. Fertilidade do solo e nutrição de plantas. Brasília: Coordenação de Agroecologia - Ministério da Agricultura, Pecuária e Abastecimento, 2012. Disponível em: http://www. agricultura.gov.br/assuntos/sustentabilidade/organicos/ fichas-agroecologicas/arquivos-fertilidade-do-solo/12biofertilizante-enriquecido-com-microrganismoseficientes.pdf. Acesso em: 2 ago. 2017.

LEONEL, S.; FRAGA A.; J.; TECCHIO, M.A.Biofertilização adubação organomineral: concentração de nutrientes na folha e produtividade de frutos de pinheira. Irriga, Botucatu, v. 1, n.1, p.40, 2015.

LOPEZ, M.A.R.; JUNQUEIRA, A.M.R.; MIGUEL, M.L.Estabilidade do biofertilizante Supermagro. Revista Brasileira de Agroecologia, Porto Alegre, v.11, n.2, p., 2016. Disponível em:http://revistas.aba-agroecologia.org. br/index.php/rbagroecologia/article/view/16195. Acesso em: 04 maio. 2020.
POLETTO, I.; MUNIZ, M.F.B.; POLETTO, T.; STEFENON, V.M.; BAGGIOTTO, C.; CECONI, D.E.Germination and development of pecan cultivar seedlings by seed stratification. Pesquisa Agropecuária Brasileira, DF, v.50, n.12, p.1232-1235, 2015.

SILVA,A.F.; PINTO, J.M.; FRANÇA, C.R.; FERNANDES, S.C.; GOMES, T.D.A.; DA SILVA, M.S.L.; ANB, M.Preparo e uso de biofertilizantes líquidos. Brasília: Embrapa Semi-Árido, 2007. (Comunicado técnico). Disponível em: http://www.infoteca.cnptia.embrapa.br/ infoteca/handle/doc/153383. Acesso em: 04 maio. 2020.

TAIZ, L.; ZEIGER, E.; MØLLER, I.M.; MURPHY, A.Fisiologia e desenvolvimento vegetal. 4.ed. Porto Alegre:Artmed, 2009. p.30.

WOOD, B.W.; STAHMANN, D. Hedge pruning pecan. HortTechnology, Alexandria, v.14, n.1, p.63-72, 2004.

WELLS, M.L. Pecan tree productivity, fruit quality, and nutrient element status using clover and poultry litter as alternative nitrogen fertilizer sources. HortScience, St Joseph, v.47, n.7, p.927-931, 2012. 